\title{
Histone Acetyltransferase KAT8
}

National Cancer Institute

\section{Source}

National Cancer Institute. Histone Acetyltransferase KAT8. NCI Thesaurus. Code C73695.

Histone acetyltransferase KAT 8 ( $458 \mathrm{aa}, \sim 52 \mathrm{kDa}$ ) is encoded by the human KAT 8 gene. This protein is involved in both histone acetylation and transcriptional regulation. 